\title{
Standard Practices for an Effective Competitive Tendering Process for Public Works Procurement
}

\author{
Sazoulang Douh \\ Building Department, National High School of Public Works (ENSTP), University of N'Djamena, Chad
}

Copyright $(2016$ by authors, all rights reserved. Authors agree that this article remains permanently open access under the terms of the Creative Commons Attribution License 4.0 International License

\begin{abstract}
This paper is a desktop study that targets the identification of standard practices for an effective competitive tendering process for public works procurement in developing countries. After defining the process and detailed activities involved, it was divided into five following phases: tender planning, tender documentation, tender solicitation, tender evaluation and tender pre-award. Then, an intensive analysis of different public procurement laws and related documents of seven developing countries was performed. As results, 38 standard practices were identified. Using the frequencies and relative frequencies, 33 were found implemented in the seven developing countries and only 20 representing $52.64 \%$ attracted frequencies above 5/8. The study found that following practices are the most frequent: develop a realistic procurement plan, accurate budget, get approvals and publish it, appoint suitable design team, obtain a complete project design, select appropriate tendering option; secure project design quality, use standard documents, review and approve tender documents before publication; advertisement of tender proposals, proper handling of requests for clarification, etc. The study concludes that when these practices are fully implemented, they will surely produce the predicted results.
\end{abstract}

Keywords Standard Practices, Competitive Tendering, Works Procurement, Developing Countries

\section{Introduction}

In public works procurement, Competitive Tendering (CT) is widely recognized as an attractive procurement mechanism due to its widespread benefits. These include promoting competition and hampering corruption [1], reducing cost by broadly $20 \%$ [2], and providing the enabling environment for effective utilization of scarce resources in the economy [3]. Consequently, CT is strongly advocated by international organizations like World Bank (WB), European Union (EU),
African Development Bank (AfBD), and the Organization for Economic Co-operation and Development (OECD). As a result, the majority of developing countries prescribed it as the prime method of public works procurement. Although CT appears to be the most acceptable method of selecting contractors [4], and the most beneficial to local construction industries [5], its implementation has been the most difficult in developing countries [3]. For instance, despite the reforms of Public Procurement Acts, Regulations and Procedures that consecrated the standardization of tender documents in the majority of developing countries, the implementation of CT remains challenged by excessive delay imputable to a lengthy process; and fraudulent and corrupt practices do persist. Furthermore, losses of time and cost due to long process are estimated between 20 to $30 \%$ of grant-in-aid according to OECD-DAC (Development Assistance Committee) [6].

This situation has led to Paris Declaration on the Aid Effectiveness for partner countries; which declaration stressed the urgent need for improvement of effectiveness in Public Procurement practices [6]. Therefore, the present study aims at identifying the key activities that can be standardized in order to improve the effectiveness of Competitive Tendering Process (CTP) in public works procurement in developing countries. Two specific objectives are set: define the main phases of the process at pre-contract stage and identify the most frequent practices for standardization. A part from introduction and conclusion, the paper is structured into three sections. The first section briefly presents literature review followed by the method employed while the third section presents the main findings including results discussion.

\section{Literature Review}

Standard practice refers to widely accepted and core activity, technique, principle, method or process that is regarded as effective to achieve certain goals in a sector or sphere of business [7], [8], [9]. In addition, it is a best practice that has shown through experience to consistently lead to the desired result and when executed effectively leads to superior project 
performance. Not only that, standardization is a way of prompting the process by a limited number of key practices [10]. Therefore, the standardization aims at gathering and harmonizing a limited number of key practices that can enable a process to be effective and easy to implement and to generalize.

Based on these assertions, seven Public Procurement Acts of developing countries were thoroughly reviewed. Though the competitive tendering process may vary from one country to another despite the reforms undertaken in 2000s, a typical process can be divided into five following main phases: Tender planning, Tender documentation, Tender solicitation, Tender evaluation and Tender award. Concerning the practices, Patrice [11] has identified 47 steps or activities from tender planning up to the award of contract in Chad Republic. Another recent study of Douh [12] has identified 49 activities ranging from needs assessment up to works commissioning. Undoubtedly, such process is not only very long and laborious but it is responsible of excessive delays in project delivery. Besides, the compilation of consulted sources has found about 38 most frequent activities distributed along the five phases of the competitive tendering process at pre-contract stage. Therefore, there is obviously a need for shortening the process by a way of standardization. The complete list of these activities is tabulated in the third section.

\section{Method}

The study adopted a mixed method with desk study using secondary data and descriptive statistic. Principal sources are Public Procurement Acts or Laws, regulations and associated manuals of procedures, procurement bulletins, periodic reports, and casual study reports. Using non-probability sampling technique, a judgmental sample of eight (8) Public Procurement Acts including seven developing countries is purposively selected. These countries are Ghana, Chad, Cameroun, Uganda, Rwanda, Senegal, and Kenya and United Nations Commission on International Trade Law (UNICITRAL) which is used for benchmarking [13, 14, 15, $16,17,18,19]$.

Then, a methodology involving three steps is used for data analysis. First, an intensive literature review has resulted in a list of 38 core practices. Second, the identified practices were checked against the articles of the Acts including those of UNICITRAL [20]. Third, using frequencies of occurrence, every identified practice is assessed. Thus, a variable that has occurred 5 times over the 8 sources will score $5 / 8$ (i.e. $62.5 \%$ ) and is considered as very common and therefore qualified for standardization.

\section{Results and Discussion}

As introduced above, the literature review has revealed a list of 38 core practices which is displayed in Table 1 below with their respective sources. Based on this list, the above method was used to analyze and establish the most common practices that can be adopted as standard practices in developing countries. 
Table 1. Standard practices of Competitive Tendering Process in some Developing Countries

\begin{tabular}{|c|c|c|c|c|c|c|c|c|c|c|}
\hline \multicolumn{2}{|r|}{ Baseline Standard/Best practices } & \multirow[t]{2}{*}{ Chad } & \multirow[t]{2}{*}{ Ghana } & \multirow[t]{2}{*}{ Kenya } & \multirow[t]{2}{*}{ Rwanda } & \multirow[t]{2}{*}{ Senegal } & \multirow[t]{2}{*}{ Cameroun } & \multirow[t]{2}{*}{ Uganda } & \multirow[t]{2}{*}{ UNCITRAL } & \multirow[t]{2}{*}{ Others } \\
\hline A. & Tender Planning Phase & & & & & & & & & \\
\hline 1. & Needs assessment and formulation of project initial brief & Art 14 & S 21 & & & Art 5 & Art 6 & Art 58 & & \\
\hline 2. & Publication of approved Annual Procurement Plan & Art 14 & S 21 & & Art 6 & $\begin{array}{c}\text { Art } 6, \\
56\end{array}$ & Art 6 & Art 54,58 & Art 6 & \\
\hline 3. & Provision of an adopted accurate estimate in the national budget & Art 15 & & & & Art 8 & Art 6 & Art 58 & Art 12 & \\
\hline 4. & Selection of an appropriate Tendering Option & Art 36 & & & & & & Art 63 & Art 26 & \\
\hline 5. & Appointment of an Independent and Free Tender Committee & Art 22 & S 17 & Art 28 & & Art 36 & & Art 26, 38 & & \\
\hline 6. & Development of detailed project design by competent professionals & Art 15 & & & & Art 5 & & Art 31 & & \\
\hline B. & Tender Document Development Phase & & & & & & & & & \\
\hline 7. & Provision of complete project design documentation & & & & & & Art 6 & Art 59 & & \\
\hline 8. & Setting of Non-discriminatory Eligibility/Participation conditions & Art 15 & S 22 & & & Art 46 & Art 17 & Art 43, 63 & Art 8 & \\
\hline 9. & Use of Standard Tender Documents & & S 50 & Art 52 & & Art 10 & & Art 56 & Art 39 & \\
\hline 10. & Use of neutral \& standard Technical specifications & Art 15 & S 49 & Art 34 & Art 25 & Art 7 & & Art 61 & Art 10 & \\
\hline 11. & Pre-disclosure of Evaluation criteria and expected terms of contract & Art 29 & & & & & & Art 71 & & \\
\hline 12. & Pre-disclosure of Tender Award criteria & & & & & & & Art 66 & Art 11 & \\
\hline 13. & Alignment with primary \& secondary objectives & Art 7 & & Art 39 & & & & & & \\
\hline 14. & Requirement of approval of Tender documents or No-objection & $\begin{array}{c}\text { Art15, } \\
23,30\end{array}$ & & & & Art 58 & & & & \\
\hline C. & Solicitation of Tenders Phase & & & & & & & & & \\
\hline 15. & Pre-Tender meeting & & & & & & & & & Papyrus \\
\hline 16. & Allocation of sufficient time to Advertisement of tender proposals & Art 30 & S 44 & Art 54 & Art 28 & Art 63 & Art 20 & & Art 33 & \\
\hline 17. & Use of multiple and/or dedicated media for Tender Advertisement & Art 30 & $\mathrm{~S} 44$ & Art 54 & Art 29 & Art 63 & Art 20 & & Art 33 & \\
\hline 18. & Grant of enough time for preparation of Tender Bids & & & Art 55 & Art 29 & Art 63 & & Art 64 & Art 33 & \\
\hline 19. & Sale of Tender document at a minimum price & & & & & Art 58 & & & & \\
\hline 20. & Reception and response to Requests for Clarifications & Art 38 & S 51 & & & Art 66 & & Art 65 & Art 15 & \\
\hline 21. & Submission/ Reception/of Tenders and Public Opening of Bids & Art 51 & S 56 & Art 58, 60 & Art 32,34 & Art 67 & Art 25 & Art 68 & Art 40,42 & \\
\hline D. & Evaluation of Bids Phase & & & & & & & & & \\
\hline 22. & Constitution of qualified and ethical Tender Evaluation Panel & Art 52 & S 63 & Art 44, 139 & Art $15-17$ & $\begin{array}{c}\text { Art } \\
38,40 \\
\end{array}$ & & & Art 26 & \\
\hline 23. & Appointment of an Independent Observer to monitor the process & Art 22 & S 19 & & & & Art 96 & Art 37 & & \\
\hline & Evaluation of tenders using Points system of scoring & & S 58 & Art 66 & Art 39 & $\begin{array}{c}\text { Art } \\
68-70\end{array}$ & Art 27 & & Art 43 & \\
\hline
\end{tabular}




\begin{tabular}{|c|c|c|c|c|c|c|c|c|c|c|}
\hline 25. & Requiring of necessary clarification of bids & Art 52 & S 57 & Art 62 & Art 38 & & & Art 73 & Art 16 & \\
\hline 26. & Requiring of tender security covering the Validity Period & Art 66 & S 54,55 & Art 57, 61 & Art 31,35 & $\begin{array}{l}\text { Art } \\
113 \\
\end{array}$ & Art 23 & & Art 17,41 & \\
\hline 27. & Appropriate use of Margin of Preference & Art 13 & S 60 & & Art 41 & Art 50 & Art 31 & & & \\
\hline 28. & Risk analysis (Construction Industry Data Base) & & & & & & & & & CIDB \\
\hline 29. & Production and Signature of Tender Evaluation Report & Art 52 & & & & Art 83 & & & & \\
\hline E. & Pre-Award Phase & & & & & & & & & \\
\hline 30. & Provision of Complete recordkeeping of procurement proceedings & & S 27,28 & Art 45 & Art 8 & Art 83 & & Art 41,55 & Art 25 & \\
\hline 31. & Pre-Award meeting and Review of Tender evaluation report & & & & & & Art 31 & & Art 22 & \\
\hline 32. & Requirement of the No-objection of Tender Evaluation Report & Art 55 & & & & Art 83 & & & & \\
\hline 33. & Commit and secure necessary funds (Attestation of Availability) & & & & & & & & & \\
\hline 34. & Publication of tender results including successful \& Unsuccessful & & & Art 46,67 & Art 43 & $\begin{array}{c}\text { Art } \\
85-87\end{array}$ & Art 33 & Art 54 & Art 23 & \\
\hline 35. & Debriefing meeting with successful and Unsuccessful tenderers & & & & & & & & & \\
\hline 36. & Right to challenge and appeal tender procedures (complain/ dispute & & & Art 93 & & Art 88 & Art 95 & & Art 64 & \\
\hline 37. & Provisional award of contract & Art 55 & & Art 67 & Art 43 & Art 84 & Art 33 & & & \\
\hline 38. & Pre-Contract Audit (Government of Jamaica) & & & & & & & & & GOJ \\
\hline
\end{tabular}


From the Table 1, out of the identified 38 practices, 33 were found implemented in developing countries but only 20 representing $52.64 \%$ attracted frequencies varying above 5/8. Among the 20 most common practices presented in Table 2 below, only 16 have been identified as very common in developing countries representing $42 \%$. The rest four practices are provided by UNICITRAL and are: Selection of an appropriate Tendering Option, Pre-disclosure of tender Award criteria, Pre-Award meeting to Adopt Tender evaluation report, and Right to challenge and appeal tender procedures. Even though these last practices are not formally prescribed in Public Procurement Acts of developing countries, they are implemented for major projects in Chad and Ghana as best practices in the area of procurement.

Table 2. Core practices and Frequencies

\begin{tabular}{|c|c|c|}
\hline & Relevant Standard practices & Mark $(>8)$ \\
\hline A. & Tender Planning Phase & \\
\hline 1. & Publication of approved Annual Procurement Plan & 7 \\
\hline 2. & Needs assessment and formulation of project initial brief & 5 \\
\hline 3. & Provision of an adopted accurate estimate in the national budget & 5 \\
\hline 4. & Appointment of an Independent and Free Tender Committee & 5 \\
\hline B. & Tender Document Development Phase & \\
\hline 5. & Use of neutral \& standard Technical specifications & 7 \\
\hline 6. & Setting of Non-discriminatory Eligibility/Participation conditions & 6 \\
\hline 7. & Use of Standard Tender Documents & 5 \\
\hline C. & Solicitation of Tenders Phase & \\
\hline 8. & Reception/Submission of Tenders and Public Opening of Bids & 8 \\
\hline 9. & Allocation of sufficient time to Advertisement of tender proposals & 7 \\
\hline 10. & Use of multiple and/or dedicated media for Tender Advertisement & 7 \\
\hline 11. & Grant of enough time for preparation of Tender Bids & 5 \\
\hline 12. & Reception and response to Requests for Clarifications & 5 \\
\hline D. & Evaluation of Bids Phase & \\
\hline 13. & Requiring of tender security covering the Validity Period & 7 \\
\hline 14. & Constitution of qualified and ethical Tender Evaluation Panel & 6 \\
\hline 15. & Evaluation of tenders using Points system of scoring & 6 \\
\hline 16. & Requiring of necessary clarification of bids & 6 \\
\hline 17. & Appropriate use of Margin of Preference & 5 \\
\hline E. & Pre-Award Phase & \\
\hline 18. & Provision of Complete recordkeeping of procurement proceedings & 6 \\
\hline & Publication of tender results including successful \& Unsuccessful & 6 \\
\hline 20. & Provisional award of contract & 5 \\
\hline
\end{tabular}

The resulting relative frequencies are displayed in the Table 3 below which shows that $34.30 \%$ are specific to each country whereas five practices representing $13.16 \%$ are not prescribed at all in the Public Procurement Acts.

In conclusion, the 20 practices tabulated in Table 2 are considered very common practices and fully discussed below along the identified five phases of the competitive tendering process.

Table 3. Frequencies and Relative Frequencies

\begin{tabular}{ccc}
\hline Classes & Frequencies & Relative frequencies \\
\hline 0 & 5 & $13.16 \%$ \\
1 & 1 & $02.63 \%$ \\
2 & 8 & $21.05 \%$ \\
3 & 2 & $05.26 \%$ \\
4 & 2 & $05.26 \%$ \\
5 & 8 & $21.05 \%$ \\
6 & 6 & $15.79 \%$ \\
7 & 5 & $13.16 \%$ \\
8 & 1 & $02.64 \%$ \\
\hline Total $=$ & $\mathbf{3 8}$ & $\mathbf{1 0 0 . 0 0 \%}$ \\
\hline
\end{tabular}




\subsection{At Tender Planning Phase}

Under this phase, four practices have scored above or equal to $5 / 8$ frequencies. The first common practice is Wide, earlier and timely publication of a realistic annual procurement plan with $7 / 8$. This high score confirms the fact that procurement plan is a key element which provides contracting authority with project brief that has to comply with national or local goals and both primary and secondary objectives of development [19, 13, 21]. Not only that, timely published procurement plan allows the private sector to respond more effectively to the project requirements and specifications. Furthermore, Thai [22] states that Procurement Plan is a core document from which all tendering activities shall flow. The second practice is Ascertain the accuracy of the allocated budget with 5/8. In effect, cost has been a determinant factor in planning stage of every construction project. Most often, Governments do conduct feasibility study, prior to the budget planning, to improve the estimate accuracy. The third practice is the Appointment of an Independent and Free Tender Committee (with 5/8), for the project design and coordination team quality is a determinant success factor in construction project asserted Watermeyer [21]. The last practice at this phase is the Appropriate assessment of needs (with 5/8). Ideally, a public construction project has to meet beneficiaries' expectations and needs. Often, many Government projects fail to meet the actual needs of people when political considerations are involved. From what precedes, the most common practices that can contribute in increasing the effectiveness of CTP at planning phase can be summarized as follows: develop a realistic procurement plan based on an appropriate needs assessment including an accurate budget, widely published and managed by a suitable project team.

\subsection{At Tender Documentation Phase}

Out of the eight practices identified under this phase, only three have scored above or equal to $5 / 8$. The first is Use of neutral and standard Technical specifications with 7/8 which is in line with the recommendation of OECD/MAPS (Methodology for Assessing Procurement Systems) [23] because it limits collusive practices. The second practice with $6 / 7$ is Setting of Non-discriminatory Eligibility/Participation conditions that are able to ensure some fairness and equity to all bidders; for it is observed that eligibility conditions are designed such a way that favors some participants to the detriment of others. The last is Use of Standard Tender Documents with 5/8. Indeed, since the reforms of PPA in 2000s, there is a worldwide agreement on the mandatory use of standard tender documents in both international and national tendering transactions. Ideally, tender documentation must be complete, précised and clear in an applicable language as well including neutral specifications and non-discriminatory eligibility conditions.

\subsection{At Tender Solicitation Phase}

Five out of the six identified practices are found relevant. The first practice is the Submission or Reception of Tenders and Public Opening of Bids with 8/8. In fact, it is recommended to register all the bids received on receipt before storing them in the designated box in a prominent place and kept locked until the opening session. Then, tender opining commences immediately and must take place on the date, time, and venue advertised. A tender opening panel shall comprise at least three persons including a member of the entity's tender committee. For purpose of transparency, it is not allowed for a tender opening session to be halted or postponed once the process has begun. Following recommendations are made to guarantee the effectiveness of the process: ensure that opening session is public and minutes of proceedings are duly written and signed as well as the attendance list; and original copies of bids are secured at all times. In case of rejection, the bid must be returned unopened.

The two following practices have attracted $7 / 8$ each: Allocation of sufficient time for Advertisement of tender proposals and Use of multiple and/or dedicated media for Tender Advertisement. Solicitation of tenders begins with tender announcements and obviously, tender announcements' channels play a vital role as well as advertisement duration. A tender proposal should be advertised in a way to attract a wide pool of potential bidders by using several media and allocate sufficient time for preparation [24]. That is why regulations impose at least two national newspapers of wide circulation (Chad), a dedicated procurement gazette (Uganda, Rwanda and Kenya), Public Procurement Authority Electronic Bulletin or a website (Ghana, Senegal), or international newspapers or radio for large projects. The two last practices are Grant of enough time for preparation of Tender Bids with 5/8 and Reception and response to Requests for Clarifications with 5/8. Indeed, requests for clarifications, in all cases, have to be answered and copies placed in the procurement record file. So, any response to a tenderer must be communicated to all tenderers without identifying the author of the request. It will be noted that when a response to request for clarifications generates substantial modifications in the project, it is recommended to extend the submission date accordingly.

\subsection{At Tender Evaluation Phase}

Out of the six practices identified, five are found relevant. This has made evaluation of bids a very sensitive step in tendering process [25]. Following practices have to be considered carefully. First is the Request of tender security covering the Validity Period with 7/8. Secondly, comes the Constitution of qualified and ethical Tender Evaluation Panel with a score of $6 / 8$. In constituting the panel, the highest ethical standards shall be applied to ensure fairness, transparency and trust. To comply with international practices, an evaluation team should be selected among the 
specialists in the area and comprising at least three to six people. Lloyd [26], recommends the involvement of an independent observer on the evaluation panel because his presence helps ensure that competing bids are impartially evaluated and provides reassurance to participants as to the integrity of the evaluation process. Furthermore, no meetings or consultations between the Procurement Entity and tenderers are permitted during this phase.

The third position goes to Evaluation of tenders using Points system of scoring which has gained 6/8 indicating clearly that this system is perceived as more objective and straight forward. Requiring of necessary clarification of bids has attracted 6/8 occupying the fourth position. During the evaluation, only criteria listed in the bidding documents will be applied. And when clarification is needed, it must be required without hindering fairness and equity. The last practice is Appropriate use of Margin of Preference with a score of $5 / 8$, what is a relevant practice to accomplish some secondary objectives. Therefore, according to Appiah and Adam [27], the role of tender evaluation phase is of paramount relevance in CTP and all endeavors are to be directed towards an irreproachable evaluation process to meet the foreseen expectations and maintaining trust.

\subsection{At Tender Pre-award Phase}

Provision of Complete record keeping of procurement proceedings through an evaluation report and Publication of tender results including successful and unsuccessful are the two first practices that have the identic score of 6/8. Usually, a period of 10 to 14 days is allocated for eventual complaints, because bidders have the right to protest the results as opined Lloyd [26] as well as the procurement acts. When there is a formal founded protest, the award process is suspended till the settlement of the case. If no formal complaint is registered after the prescribed period, a provisional notification is issued to the winner who should be required to confirm in writing acceptance of the tender award and submit the appropriate performance security; after what the final notification is issued. The third practice is Provisional award of contract with $5 / 8$. After evaluation report approval, the procuring entity should send a provisional notification to both successful and unsuccessful tenderers. A debriefing is to be organized with all tenderers to publicly release tender results. Failure to do that may constitute grounds for the annulment of the award. In that event, the Procurement Entity may award the contract to the next lowest evaluated bidder, whose offer is substantially responsive and qualified to perform the contract satisfactorily. Generally, a pre-award meeting is held to review and adopt the tender evaluation report. Prior to the meeting, a formal commitment of the required funds must be done in the form of 'Funds Availability Attestation'.

Before concluding, it is worthy to add that three following practices were revealed by the study: Pre-Tender meeting applied in Papyrus, Risk analysis at pre-award phase by
Construction Industry Development Board (CIDB) [28] in South Africa, and Pre-Contract Audit by Government of Jamaica. Actually, the practice of Pre-tender meeting, suggested by Papyrus, prior the preparation of bids is relevant because it helps bidders understand the project objectives and client expectations. Risk analysis prior to the award of contract, as proposed by CIDB [28], is also a best practice for its implementation can mitigate some risks associated. Furthermore, the Pre-Contract Audit is very popular in Jamaica as well as in USA where its implementation saves up to $10 \%$ of the bid amount.

\section{Conclusions}

The study has fully defined the concept of Competitive Tendering Process and a typical process is divided into five following main phases: Tender planning, Tender documentation, Tender solicitation, Tender evaluation and Tender pre-award. Briefly, the study identified the following practices as common standard practices that can lead to an effective CTP: Develop a realistic procurement plan including an accurate budget, get the required approvals, publish it, appoint a suitable project design team, obtain a complete project design, and select an appropriate tendering option; secure project design quality, use standard documents, and review and approve tender documents before publication; wide and long advertisement of tender proposals, proper handling of requests for clarification, and publicly opening session; appoint a suitable evaluation panel team, use of points scoring system, drafting the report on time using standard format, and include a clear recommendation for the award; review and adoption of tenders evaluation report, publication of tender results, resolution of eventual complaints / disputes before final award.

It is often recommended to hold a pre-award meeting for adopting the evaluation report before the publication of the results. Lastly, giving a right to tenderers to challenge the procedures seems be a good practice that enhance equity and fairness.

Lastly, as a matter of fact, by reducing the CTP at only 20 key activities, the study has the merit of shortening the process. Not only that, when these practices are fully implemented as proposed, they would produce undoubtedly the predicted results. These advantages could be savings in time and cost by broadly $20 \%$ of total cost incurred as it is USA and Cyprus. However, it is still observed that although $\mathrm{CT}$ is the most employed method and the most beneficial to construction industries, yet its implementation remains ineffective due to the lack political will to fully enforce laws and regulations as prescribed. This can be traced to the lack of performance assessment culture in one hand and the resistance to changes in the other hand. Therefore, the study recommends a change of mind to use the standard practices in order to improve the effectiveness. 


\section{REFERENCES}

[1] Steven, T. and Patrick, B. (2006). Incentives and Award Procedures: Competitive Tendering versus Negotiations in Procurement, Unpublished paper, Retrieved June 21, 2011 from $w w w . c o m p e t i t i v e . t e n d e r i n g /$

[2] Simon, D., Shirley, M. and David, T. (2005). The Impact of Competitive Tendering on the Costs of Hospital Domestic Services, Unpublished paper, Retrieved June 21, 2011 from www.wiley-onlinelibrary/

[3] Dikko, H. A. (2000). Competitive Tendering - A Holistic Approach. In: Open and Competitive Tendering in the Procurement of Public and Private Sector Projects. Nigeria Institute of Quantity Surveyors (NIQS), Lagos, Nigeria

[4] Akubueze, P. N. (2000). Open and Competitive Tendering in the Procurement of Public Projects. In Open and Competitive Tendering in the Procurement of Public and Private Sector Projects. Nigeria Institute of Quantity Surveyors (NIQS), Lagos, Nigeria

[5] Oladepo, M. A. (2000). Open and Competitive Tendering - A vehicle for Transparency and Accountability in Governance. In: Open and Competitive Tendering in the Procurement of Public and Private Sector Projects. Nigeria Institute of Quantity Surveyors (NIQS), Lagos, Nigeria

[6] OECD-DAC. (2005). The Paris Declaration on Aid Effectiveness. Adopted at the first High-Level Forum on Aid Effectiveness, Paris March 2 ${ }^{\text {nd }}, 2005$

[7] Williams-Elegbe, Sope (2009). A comparative analysis of the Nigerian Public Procurement Act against international best practice, Unpublished paper, Department of Public Law, Faculty of Law, University of Stellenbosh; sope.williams@yahoo.co.uk

[8] Arendale, D. (2010), What is a best education practice? University of Minesota

[9] Watermeyer R. B. (2012). Changing the Construction Procurement Culture to improve project outcomes, In: Joint CIB W070, W092 and TG72 International Conference on Facilities Management, Procurement Systems and Public Private Partnerships, Cape Town, 23rd to 25th January 2012.

[10] Douh, S., Adjei-Kumi, T., and Adiniyira, E. (2014). A conceptual framework for assessing the effectiveness of public works procurement process at pre-contract stage in Chad Republic In Third ICIDA Conference Procs., 17-19 March 2014, Abeokuta, Nigeria

[11] Patrice E. M. (2008). Etude pour l'amélioration de l'efficacité de la Passation des Marchés Publics au Tchad: Rapport Diagnostic (R1), N’Djaména, Tchad.

[12] Douh, S. (2015). A framework for Assessing the Effectiveness of Competitive Tendering Process at Pre-Contract Stage for Public Works Procurement in Chad Republic, $A$ PhD dissertation, KNUST, Kumasi, Ghana
[13] Republic of Ghana (2003). Public Procurement Act - Act 663, Ghana

[14] Republic of Kenya (2005). The Public Procurement and Disposal Act - Act 3 on $26^{\text {th }}$ October 2005, In Kenya Gazette Supplement No 77.

[15] Republic of Rwanda (2007). Law on Public Procurement - Act $12 / 2007$.

[16] Republic of Uganda (2003). The Public Procurement and Disposal of Public Assets Act - Act 1 on $17^{\text {th }}$ January 2003, In The Uganda Gazette No 3, Vol. XCVII.

[17] République du Cameroun, (2004). Code des Marches Publics, Retrieved from www.Droit-Afrique.com

[18] République du Sénegal (2011). Décret 2011 - 1048 Portant Code des Marches Publics, publie le 27 Juillet 2011, Dakar, Senegal

[19] République du Tchad, (2003). Decret 503 Portant Code des Marches Publics, Journal Officiel du 05 Décembre 2003, N'Djaména, Tchad

[20] UNCITRAL, (2009). Model Law on Procurement of Goods, Construction and Services.

[21] Watermeyer, R. B. (2013) Value for money in the delivery of public infrastructure In: Laryea, S. and Agyepong, S. (Eds) Procs 5th West Africa Built Environment Research (WABER) Conference, 12-14 August 2013, Accra, Ghana, 3-19.

[22] Thai, K. V. (2009). International Public Procurement: Concepts and Practices. In International handbook for Public Procurement (Chapter 1).

[23] OECD/MAPS. (2010). Methodology for Assessing Procurement Systems (MAPS), February 2010.

[24] Arrowsmith, S., (2009). European Community (EC) Regime on Public Procurement. In: K.T. Thai, ed. International Handbook for Public Procurement. New York: CRS Press, pp. 251-290.

[25] GOJ - Government of Jamaica, (2010). Procurement Best Practice Guide 2: Tender Processes and Tender Documents

[26] Lloyd, E.R. (2009). Bid Protests: Theory and Practice. In: K.T. Thai, ed. International Handbook for Public Procurement. New York: CRS Press, pp. 659-672.

[27] Appiah, R. and Adam, M. (2013). Duration of Tender Evaluation - Its effect on Procurement Process, In Ghana Public Procurement Authority E. Bulletin, Vol. 4, Issue 1, pp. 2-5.

[28] CIDB - Construction Industry Development Board. (2006). Construction Procurement: Best Practice Guideline \#A3, Evaluating tenders offers, August 2006. Third edition of CIDB document 1003. 